\title{
Conventional and molecular biotyping of Brucella strains isolated from cattle, sheep and human"
}

\author{
Tuba İÇA ${ }^{1}$, Fuat AYDIN ${ }^{1}$, K. Semih GÜMÜŞSOY ${ }^{1}$, Duygu PERÇİN ${ }^{2}$, Ahmet Bülent SÜMERKAN², \\ Fulya OCAK ${ }^{3}$, Seçil ABAY ${ }^{1}$, H. Okan DOGAN ${ }^{4}$, Arzu FINDIK ${ }^{5}$, Alper ÇíFTCí ${ }^{5}$ \\ ${ }^{1}$ University of Erciyes, Faculty of Veterinary Medicine, Department of Microbiology, Kayseri, ${ }^{2}$ University of Erciyes, Faculty of \\ Medicine, Department of Microbiology, Kayseri, ${ }^{3}$ University of Celal Bayar, Faculty of Science and Arts, Department of Biology, \\ Manisa, ${ }^{4}$ Ankara Numune Education and Research Hospital, Emergency Biochemistry Laboratory, Ankara, ${ }^{5}$ University of Ondokuz \\ Mayis, Faculty of Veterinary Medicine, Department of Microbiology, Samsun, Turkey.
}

Summary: In this study, the role of Brucella spp. in cattle and sheep abortions among Kayseri region was investigated and predominant subspecies and biovars in this region were determined by conventional and molecular biotyping methods. For this purpose, 61 cattle and 64 sheep abortion material and also 50 human blood isolates were examined. A total of 29 Brucella spp. 17 $(27.9 \%)$ and $12(18.7 \%)$ of which were isolated from cattle and sheep specimens, respectively) were isolated from animal sources. Both animal and human isolates were typed by conventional and Enhanced AMOS-ERY PCR methods. All Brucella spp. strains isolated from cattle were found to belong to B. abortus biovar 3 and biovar $3 \mathrm{~b}$ using conventional and molecular typing methods, respectively. All sheep originated Brucella spp. strains and human originated Brucella spp. strains were found to belong to B.melitensis biovar 3 using both conventional and molecular methods. As a result, predominant biovars causing brucellosis in human, cattle and sheep in Kayseri, Turkey were detected. These findings were considered to be useful in prevention and controlling activities for Brucellosis in Turkey.

Keywords: Biotyping, Brucella, enhanced AMOS-ERY PCR.

\section{Sığır, koyun ve insanlardan izole edilen Brucella suşlarının konvansiyonel ve moleküler biyotiplendirmesi}

Özet: Bu çalışmada Kayseri bölgesinde sığır ve koyunlardaki atık olgularında Brucella'nın rolü araştırıldı ve ağırlıklı alt-tür ve biyovarlar konvansiyonel ve moleküler biyotiplendirme metotları ile belirlendi. Çalışmada 61 adet sığır, 64 adet koyun atık materyali ve ayrıca 50 insan kanından izole edilmiş Brucella spp. incelendi. On yedi (\%27.9)'si sı̆̆ır ve 12'si (\%18.7) koyun atık örneklerinden olmak üzere toplam 29 adet Brucella spp. izole edildi. Hayvan ve insan izolatlanı konvansiyonel yöntemler ve Enhanced AMOS-ERY PCR olmak üzere iki farklı yöntem ile tiplendirildi. Çalışma kapsamında sığırlardan izole edilen tüm Brucella spp.'nin B.abortus biyovar 3'e ait olduğu konvansiyonel yöntemlerle saptandı ve bu izolatların tamamının moleküler olarak biyovar $3 \mathrm{~b}$ olduğu tespit edildi. Koyun ve insan orijinli izolatların ise konvansiyonel ve moleküler olarak B.melitensis biyovar 3 oldukları tespit edildi. Bu çalışma ile Türkiye'nin Kayseri İli’nde, insan, sığır ve koyunlarda Brucellosis'e neden olan predominant Brucella biovarları belirlenmiş oldu. Bu bulguların Brucellosise yönelik koruma ve kontrol aktiviteleri için yararlı olabileceği düşünülmektedir.

Anahtar sözcükler: Biyotiplendirme, Brucella, enhanced AMOS-ERY PCR

\section{Introduction}

Brucellosis caused by an intracellular pathogen which is belong to Brucella genus is one of the most important zoonotic infections worldwide as well as in Turkey. Brucella spp. cause infections mainly characterized by abortion, infertility, mastitis, arthritis and orchitis in cattle, sheep, goats and pigs. The disease is also associated with the production losses relating to decreases in milk production and breeding value and infertility. Brucellosis constitutes an important public health problem usually resulting from the transmission via direct contact with infected animals and animal products.

The diagnosis of brucellosis is usually based on serology and culture. The identification of Brucella isolates at the species and biovar levels by classical bacterial methods is time consuming because Brucella spp. requires long incubation period and several phenotypical tests are needed to determine biovars. Also, infection risk in laboratory personnel who work for

\footnotetext{
* This study was supported by Scientific Research Projects Coordination Unit of Erciyes University (EUBAP VA-05-09).
} 
diagnosis of brucellosis by laboratory tests should not be forgotten. Although serological tests are useful to diagnose of the disease, cross-reactions with some other bacteria may lead to false positive results. The requirement of more rapid and sensitive diagnostic tests for brucellosis has come into question because of the importance of disease in terms of both public and animal health and in terms of economic importance. Currently, the diagnostic methods based on the detection of nucleic acid such as Polymerase Chain Reaction (PCR) are often used because such methods meet these requirements. The range of the identification of Brucella species has been expanded using the different versions of PCR. B. abortus biovar 1, 2 and 4, three biovars of B. melitensis, B. ovis and $B$. suis biovar 1 can be identified and differentiated by Brucella AMOS (Abortus-Melitensis-Ovis-Suis)-PCR assay based on the existence of repetitive IS711 copies in the genome of different Brucella species (7). However this method is not useful for identification of all subspecies and further tests are needed. New oligonucleotide primers have been added to the multiplex Brucella AMOS PCR assay and the ability of AMOS assay to identify more number of Brucella biovars and also to discriminate between $B$. abortus vaccine strains and wild-type isolates of Brucella has been expanded. A new method, known as AMOS-ERY PCR, involves the use of ery locus-specific primers and permits all Brucella species to be identified $(8,20)$. Ocampo-Sosa et al $(20)$ have described a $5.4 \mathrm{~kb}$ deletion next to on of the IS711 copies in B. abortus biovars 5, 6 and 9 and also in some biovar 3 strains. However this deletion has not been detected in Tulya strain of biovar 3 of B. abortus (ATCC 23450) and biovar 3 strains have been classified into two subgroups named as $3 \mathrm{a}$ and $3 \mathrm{~b}$. The addition of a specific primer, DEL 569 to AMOS-ERY-PCR primer cocktail has allowed this assay to be able to determine this deletion. Thus the detection power of AMOS PCR has been enhanced (Enhanced AMOS-ERY PCR).

This study was conducted to biotype bovine, ovine and human Brucella strains isolated from different sources by conventional and molecular methods in Kayseri region of Turkey.

\section{Materials and Methods}

Collection of samples: In this study, a total of 125 aborted materials collected from the different districts of Kayseri were used, of which 64 were from cattle and 61 were from sheep. A total of 50 human Brucella strains were obtained from University of Erciyes Faculty of Medicine, Department of Microbiology, Kayseri in 2006.

Isolation of Brucella spp. from cattle and sheep: The liver, spleen and stomach contents of aborted fetuses were collected and inoculated onto supplemented (SR0083, Oxoid) Brucella Agars (CM0169, Oxoid) were performed. Agars were incubated both in aerobic and microaerobic conditions at $37^{\circ} \mathrm{C}$ for $48-96$ hours.

Conventional identification and biotyping of Brucella spp.: All Brucella strains isolated from animal and human samples were identified on the basis of colonial morphology, microscopic appearance and biochemical properties. For conventional bioyping, Brucella spp. were investigated for their $\mathrm{CO}_{2}$ requirements, production of urease and $\mathrm{H}_{2} \mathrm{~S}$, sensitivity to basic fuchsin and thionin and also agglutination with $\mathrm{A}$ and $\mathrm{M}$ monospecific sera and susceptibility to Tbilisi phage (Pendik Veterinary Control and Research Institute) $(2,5)$.

Identification and biotyping of Brucella spp. by Enhanced AMOS-ERY PCR: For molecular identification and biotyping of Brucella strains Enhance AMOS-ERY PCR was used $(7,20)$. For DNA extraction, bacteria were cultured onto $5 \%$ sheep Blood Agar at $37^{\circ} \mathrm{C}$ for $24-$ 48 hours. Then colonies were harvested and suspended with $400 \mu \mathrm{l}$ steril phosphate saline (PBS). Suspension was boiled at $100^{\circ} \mathrm{C}$ for 10 minutes and then centrifuged at $13.000 \mathrm{rpm}$ for10 minutes. Supernatant was used as template DNA for PCR.

The primer mix contained the seven primers specific for B. abortus, B. melitensis, B. ovis, an IS711 specific primer, the ERY1 and ERY2 primers specific for the eryC-eryD region from B. abortus S19 and DEL569 primer specific for $5.4 \mathrm{~kb}$ fragment deleted in some field strains and biovars of $B$. abortus. The oligonucleotides used in this study are listed in Table 1. For the $20 \mu \mathrm{l}$ of reaction mixture, $2 \mu 1$ of $10 x P C R$ buffer, $0.2 \mathrm{mM}$ of each dNTP, $1.5 \mathrm{mM}$ of $\mathrm{MgCl}_{2}, 0.28 \mu \mathrm{l}$ of IS711 primer and $0.04 \mu 1$ of the rest of the primers, $1 \mathrm{U}$ Taq polymerase and $1 \mu 1$ extracted DNA were mixed. The amplification was carried out as follows: initial denaturation at $95^{\circ} \mathrm{C}$ for $10 \mathrm{~min}, 30$ cycles of $94^{\circ} \mathrm{C}$ for $30 \mathrm{~s}, 60^{\circ} \mathrm{C}$ for $30 \mathrm{~s}$, $72^{\circ} \mathrm{C}$ for $2 \mathrm{~min}$ and a final extension at $72^{\circ} \mathrm{C}$ for $5 \mathrm{~min}$ (6). Amplicons were loaded onto $0.8 \%$ agarose gel and containing $1 \mu \mathrm{g} / \mathrm{ml}$ ethidium bromide and electrophoresed at $100 \mathrm{~V}$ for $40 \mathrm{~min}$.

Table 1. Oligonuclotides used in this study Tablo 1. Çalışmada kullanılan oligonükleotidler

\begin{tabular}{llc}
\hline Primer & Oligonuleotide sequence ( 5'-3') & Reference \\
\hline PBa & GACGAACGGAATTTTTCCAATCCC & 10 \\
PBm & AAATCGCGTCCTTGCTGGTCTGA & 10 \\
PBo & CGGGTTCTGGCACCATCGTCG & 10 \\
PIS711 & TGCCGATCACTTAAGGGCCTTCAT & 10 \\
ERY1 & CGCCTGCGTGACCTCCAGCTTACCC & 25 \\
ERY2 & GGCCATGACACGCGGCATATAACC & 25 \\
DEL569 & GCGCAGCGTTGCGGCAATTG & 25 \\
\hline
\end{tabular}

\section{Results}

Isolation of Brucella spp.: Seventeen strains (27.9\%) were isolated from 61 aborted bovine fetuses and 12 strains $(18.7 \%)$ were isolated from aborted sheep fetuses. 


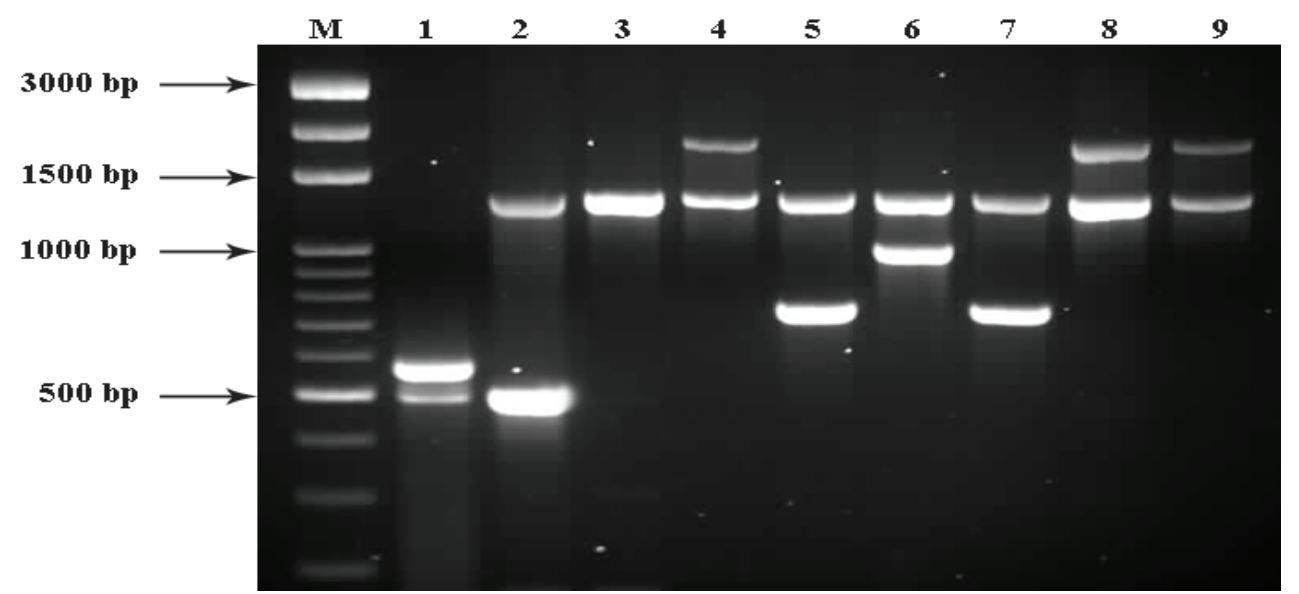

Figure 1. The results of Enhanced AMOS-ERY PCR. M. Marker, 1,2,3,5 and 6. Positive control strains: 1. B. abortus S19 strain, 2. B. abortus biovar 1, 3. B. abortus biovar 3 (Tulya), 4. B. abortus biovar 3b, 5. B.melitensis, 6. B.ovis, 4, 8 and 9. Bovine B. abortus field isolates, 7. Ovine B.melitensis field isolate.

Şekil 1. Enhanced AMOS-ERY PCR sonuçlar1. M. Marker, 1,2,3,5 ve 6. Pozitif kontrol suşları: 1. B. abortus S19 suşu, 2. B. abortus biovar 1, 3. B. abortus biovar 3 (Tulya), 4. B. abortus biovar 3b, 5. B.melitensis, 6. B.ovis, 4, 8 ve 9. Siğır B. abortus saha izolatlar1, 7. Koyun B.melitensis saha izolat1.

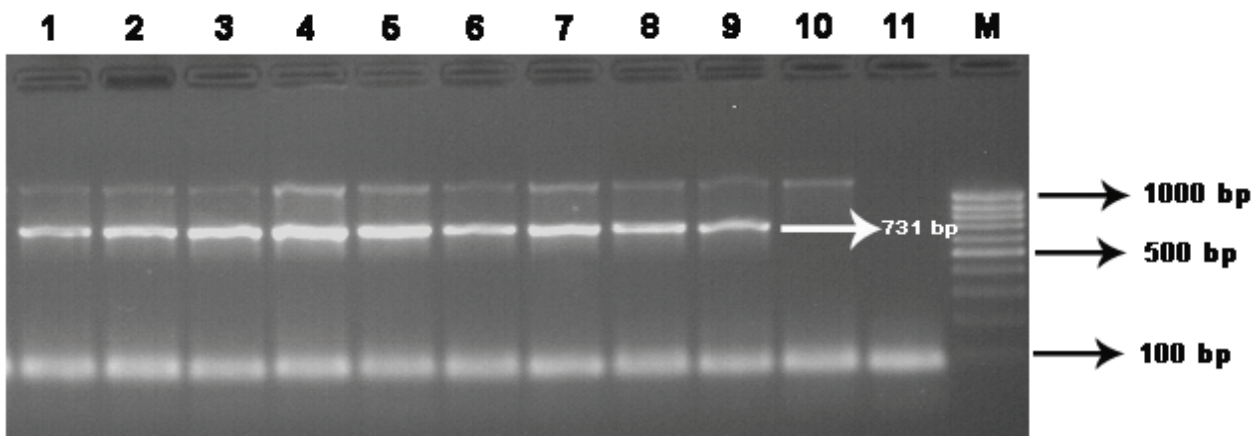

Figure 2. Human B. melitensis isolates identified by Enhanced AMOS-ERY PCR. M. Marker, 1-10 human B.melitensis isolates (731 kb) Şekil 2. AMOS-ERY PCR ile identifiye edilen insan B. melitensis izolatları. M. Marker, 1-10 insan B.melitensis izolatları (731 kb).

Conventional identification and biotyping of Brucella spp.: While all bovine isolates (17 strains) were identified as $B$. abortus, all sheep and human isolates were identified as $B$. melitensis by conventional tests. In conventional biotyping of these strains, all B. melitensis strains and bovine B.abortus strains were found to belong to biovar 3 .

Molecular identification and biotyping by Enhanced AMOS-ERY PCR: Molecular identification of all Brucella isolates at species level and molecular biotyping of these strains were performed by Enhanced AMOSERY PCR. A 1270 bp band was observed in all Brucella strains with Ery1-Ery2 primers, except for B. abortus S19 strain. In addition to this band (1270 bp), $731 \mathrm{bp}$, 498 bp, 1700 bp and 976 bp bands were observed for $B$. melitensis, B. abortus (biovar 1, 2, 4), B. abortus (biovar $3 \mathrm{~b}, 5,6,9)$ and $B$. ovis, respectively. Field isolates were differentiated from $B$. abortus S19 vaccine strain by observing two close bands which were approximately 500 bp with Ery 1-2 in S19 strain (Figure1 and 2).

Sheep and human isolates of Brucella were identified as B. melitensis by Enhanced AMOS-ERY
PCR,. Bovine Brucella isolates were identified as $B$. abortus and these strains were found as biovar $3 \mathrm{~b}$.

\section{Discussion}

Brucellosis still poses a threat both to human and animal health in many countries despite having an eradication program. The detection of predominant species and biovar/biovars among infected human and animals is the major step to develop control strategies for Brucellosis. The prevalence of brucellosis varies from region to region throughout the country however this infection is widespread particularly in developing Mediterranean and Middle Eastern countries (1, 18, 21). In this study, the prevalence of brucellosis in abortus cases of cattle and sheep in Kayseri Province was investigated. It was determined by cultural and molecular techniques and the prevalence of brucellosis in abortus cases of cattle and sheep were detected as $27.9 \%$ and $18.7 \%$, respectively. In a study conducted in Kars Province of Turkey, Brucella spp. has been isolated and identified from 37 out of $62(55.6 \%)$ aborted cattle fetuses (25). Also, Ünver et al. (25) have isolated 38\% of 
B. melitensis from aborted sheep fetuses. In another study in the same region, Brucella isolation rate from milk and vaginal samples from cattle has been detected as $4.4 \%$ and $6.4 \%$, respectively (12). Gülhan et al. (16) have detected the percentage of Brucella spp. isolation from aborted cattle fetuses as $26.7 \%$. The isolation rate of Brucella spp. shows great variety between regions of Turkey, even in the same region. This may related to different management and climatic conditions, different sources of samples from which the isolation is performed.

Human brucellosis has serious public health consequences in endemic areas. Worldwide, among all Brucella species, Brucella melitensis is the most prevalent species causing human brucellosis. Especially in countries where animal brucellosis has not be able to control yet, due to inadequate food-safety measures, absence of effective hygienic control and laboratory safety, millions of human beings are at risk. Also Turkey is an endemic country for brucellosis $(3,13)$. According to reports from the Turkish Ministry of Health, 37 cases were reported in 1970, with numbers rising to 18408 cases in 2004 (incidence rate 25.67/100 000). This increase is considered to be a result of improvements in diagnosis and increased reporting, rather than a real increase in the prevalence of the disease (9). Especially in developing countries as well as in Turkey, because the case definitions are not truly made, true incidence and prevalence can not be estimated. Therefore, although brucellosis is a notifiable disease in Turkey, reported prevalence values can not thought to be actual figures. One of the important reason for this faulty is poorly organized health centers that not operate harmoniously for true case definitions throughout the country. Sümerkan et al. (22), have reported that approximately 50-60 B. melitensis were isolated from 8000 blood samples per year in Kayseri and that Brucellosis caused by $B$. melitensis was endemic in this region. Also in this study, a total of 50 Brucella spp. strains from blood samples collected from a hospital in which 20.000 patients sample are examined and all were identified as B. melitensis.

Brucella isolates from cattle and sheep as well as human Brucella spp. strains isolated from blood samples were identified and biotyped both by conventional and molecular methods (Enhanched AMOS ERY PCR). In this study, 17 Brucella spp. isolated from bovine aborted fetuses were identified as B.abortus biovar 3 and biovar $3 \mathrm{~b}$ by conventional and molecular methods, respectively. Twelve isolates from ovine abortus were identified as B.melitensis biovar 3 both by these two methods. Ocampo-Sosa et al. (20) have conventionally biotyped 129 Brucella field isolates in Cantabria, Spain and have found that most of the strains, $115(89.14 \%)$ were $B$. abortus biovar 3. Eleven (8.52\%), $1(0.77 \%)$ and two
(1.55\%) strains have identified as B.abortus biovar 1, biovar 2 and B. melitensis biovar 2, respectively. Büyük and Şahin (10) have reported that $87.61 \%$ of B. abortus isolates from cattle were biotyped as biovar 3 in their study. Büyükcangaz et al. (11) have conventionally biotyped $B$. melitensis isolates and most of them have found as biovar 3. In investigations that have carried out in the Kars province (23), most isolates (93.75\%) were found to belong to biovar 3. Also in different regions of Turkey, B. melitensis isolates from various sources have mostly biotyped as biovar $3(14,15)$. The biotyping results obtained in this study comply with the results of previous studies mentioned above and show that the predominant biovar of both B. abortus and B.melitensis is biovar 3 .

Bolca et al (4) have reported that $75.86 \%$ of $B$. melitensis strains that they were isolated from various samples of humans were typed as biotype 3 , the remains were found as biotype $1(13.79 \%)$ and were found to have rough colony morphology $(10.34 \%)$. In a recent study (24), it has been reported that all Brucella strains isolated from human diagnosed with brucellosis in Central Anatolia Region of Turkey were identified as $B$. melitesis and $92.8 \%$ of them were conventionally typed as biotype $3,57.2 \%$ as biotype 1 . In this study, after conventional and molecular typing of fifty human Brucella strains isolated from blood samples, they were all identified as B.melitensis biovar 3. Therefore, the most prevalent type of $B$. melitensis from human brucellosis seems to be biovar 3 .

Due to the close genetic similarity among Brucella species and the strains in Brucella genus, the differentiation of species and biovars is difficult by conventional methods. Furthermore, the instability for some of the phenotypic characteristics of Brucella that have been reported by Meyer (19), makes it difficult to identify some particular strains. Furthermore because it is very risky to handle live Brucella in terms of possible laboratory infection, for handling samples and live bacteria for eventual identification and biotyping, the level 3 biocontainment facilities and highly skilled technical personnel are required. In order to avoid these disadvantages, methods based on PCR are becoming very useful and to date considerable progress has been made in the development of more sensitive, specific, easier and cheaper PCR techniques for Brucella detection (26). It has been reported that several researchers have described various PCR assays for both diagnosing and typing of Brucella species (20). Among them a genus specific PCR firstly developed for Brucella have been unable to differentiate Brucella species. Then AMOS (from the initial letters of abortus, melitensis, ovis and suis) PCR assay developed by Bricker and Halling (7) have been reported to be able to identify and differentiate most Brucella species. Because of inadequacy in 
differentiation of all biovar and species new oligonucleotides have been added to AMOS-PCR primer cocktail to identify more number of Brucella biovars and also to discriminate between $B$. abortus vaccine strains and wild-type isolates of Brucella (AMOS-ERY PCR). Then, another specific primer, DEL569 designed for a $5.4 \mathrm{~kb}$ deletion next to one of the IS711 copies in B. abortus biovars 5, 6, 9 and in some field strains of biovar 3 of $B$. abortus has been added to the AMOS-ERY-PCR primer cocktail. Thus, AMOS-ERY-PCR has become more distinctive to discriminate B. abortus biovars $3 \mathrm{~b}, 5$, 6 and 9 from the rest of Brucella species and biovars and its name has been called as Enhanced AMOS-ERY-PCR. While Tulya strain and the field strains isolated from Africa have been suggested to belong to biovar $3 \mathrm{a}$, the European field strains have been suggesed to belong to group 3b (20). Ica et al. (17), have subtyped all 75 Brucella abortus strains isolated from aborted bovine fetuses in several regions of Turkey as B. abortus biovar $3 \mathrm{~b}$ by enhanced AMOS-ERY PCR. Similarly in this study, all B. abortus strains isolated from bovine aborted fetuses were typed as biovar $3 \mathrm{~b}$ using AMOS-ERY PCR. This result shows that $B$. abortus biovar $3 \mathrm{~b}$ is the predominant subtype in Kayseri provinces of Turkey. Although some reports concerning the conventional biotyping of $B$. melitensis isolates originated from sheep materials, it has not been found any report concerning molecular biotyping of $B$. melitensis in Turkey. In this study all $B$. melitensis isolates were biotyped by a conventional method and described as biovar 3 . Furthermore, human B. melitensis isolates were also identified as biovar 3 using the same technique. This shows that same biovar (biovar3) of $B$. melitensis is predominant in Kayseri.

As well as in many countries of the world, in Turkey a vaccination program is implemented to eradicate Brucellosis. For this aim, B. abortus S19 vaccine is used in cattle. In some cases, there are some complaints about vaccine associated infections. The reliable differentiation of vaccine strains from feld isolates is an important element in brucellosis control programs. The conventional methods can not meet this requirement however $B$. abortus $\mathrm{S} 19$ vaccine strain is readily differentiated from field strains by Enhanced AMOS-ERY PCR. In this study, none of the bovine isolates were B. abortus S19.

In Kayseri Province, although the role of Brucella spp. was found in bovine and ovine abortus cases examined in this study, the rates of Brucellosis were relatively low $(27.9 \%$ and $18.7 \%$ in bovine and ovine abortus cases, respectively). Further studies should be performed to detect other agents causing abortion. This is important to maintain breeding activities economically.

In conclusion, Enhaced AMOS-ERY PCR was found to be useful as a rapid, easy and discriminative method in this study. Besides conventional methods, Enhanced AMOS-ERY-PCR as a molecular biotyping method provided the identification of predominant biotypes of Brucella strains in Kayseri province of Turkey. To control brucellosis, the results of this study and further more detailed studies concerning the identification and characterization of dominant strains throughout the country are considered to be helpful, especially for vaccine development studies.

Epidemiological data obtained from this study may be useful to evaluate local situation of brucellosis in Kayseri and they may allow us to detect predominant biovar/biovars in this area. Especially latter is significant in prevent and control activities for brucellosis.

\section{References}

1. Al-Ani FK, Qaderi NQ, Razziq R, Al-Darraji AM (2004): Human and animal brucellosis in Jordan between 1996-1998: a study. Rev Sci Tech Off Int Epizoot, 23, 831-840.

2. Alton GG, Jones LM, Pietz DE (1975): Laboratory Techniques in Brucellosis. Monograph Series. World Health Organization, Geneva, Switzerland.

3. Anon (2011): WHO, Brucellosis, http://www.who.int/ zoonoses/diseases/ Brucellosissurveillance.pdf.

4. Bolca Z, Gündeș S, Erdenliğ S, Özturk R, Sümerkan B, Akata, F, Vahaboğlu, H (2002): Insan kaynakl brusella türü mikroorganizmaların tiplendirilmesi amacı ile uygulanan metotların karşılaştırılması ve biyotipleri ile faj tipleri arasındaki ilişkinin irdelenmesi. Flora, 7(3), 157170.

5. Bricker BJ (2002a): Diagnostic Strategies Used for the Identification of Brucella. Vet Microbiol, 90, 433-434.

6. Bricker BJ (2002b): PCR as a Diagnostic Tool for Brucellosis. Vet Microbiol, 90, 435-446.

7. Bricker BJ, Halling SM (1994): Differentiation of Brucella abortus by 1, 2, and 4, Brucella melitensis, Brucella ovis, and Brucella suis bv. 1 by PCR. J Clin Microbiol, 32, 2660-2666.

8. Bricker BJ, Halling SM (1995): Enhancement of the Brucella AMOS PCR assay for differentiation of Brucella abortus vaccine strains S19 and RB51. J Clin Microbiol, 33, 1640-1642.

9. Buzgan T, Karahocagil MK, Irmak H (2010): Clinical manifestations and complications in 1028 cases of brucellosis: a retrospective evaluation and review of the literature. Int J Infect Dis, 14, 469-478.

10. Büyük, F, Şahin M (2011): Invesigation of Brucella species from various samples of aborted cattle in Kars Province (Turkey) by cultural and molecular methods and epidemiological analysis of cases, The Journal of the Faculty of Veterinary Medicine, University of Kafkas, 17 (5), 809-816.

11. Büyükcangaz E, Şen A, Kahya S (2009): Isolation and Biotyping of Brucella melitensis from Sheep and Goat Aborted Fetuses. Turk J Vet Anim Sci, 33, 311-316.

12. Çelebi Ö, Otlu S (2011): Bacteriological and Molecular Description of Brucella SpeciesIsolated from Milk and Vaginal Swab Samples of Aborted Cattlein Kars Region. 
The Journal of the Faculty of Veterinary Medicine, University of Kafkas, 17 (1), 53-58.

13. Doğanay M, Aygen B (2003): Human Brucellosis: an overview, Int J Infect Dis, 7, 173-182.

14. Erdenliğ S, Sen A (2000): Isolation and biotyping of Brucella species in aborted sheep fetuses. J Pendik Vet Microbiol, 31, 31-42.

15. Güler L, Gündüz K, Ok U (2003): Comparison of polymerase chain reaction and bacteriological culture for the diagnosis of sheep brucellosis using aborted fetus samples. Vet Microbiol, 93, 53-61.

16. Gülhan, T., Aksakal, A, Ekin, İH, Boynukara B (2011): Retrospective Evaluation of Examined Materials for Diagnosis in University Yuzuncu Yil Faculty of Veterinary Medicine Microbiology Department Laboratory. Yüzüncü Y1l Üniversitesi Veteriner Fakültesi Dergisi, 22 (2), 127132.

17. Ica T, Aydin F, Erdenlig S, Güler L, Büyükcangaz E (2008): Characterisation of Brucella abortus biovar 3 isolates from Turkey as subgroup 3b. Vet Rec, 163, 659661.

18. Kubuafor DK, Awumbila B, Akanmori BD (2000): Seroprevalence of brucellosis in cattle and humans in the Akwapim-South district of Gahana: public health implications. Acta Tropica, 76, 45-48.

19. Meyer ME (1976): Evolution and taxonomy in the genus Brucella: progesterone induction of filterable forms of Brucella abortus type 2 with revertant characteristics essentially indistinguishable in vitro from those of Brucella ovis. Am J Vet Res, 37, 211-214.

20. Ocampo-Sosa AA, Balblin JA, García-Lobo JM (2005): Development of a new PCR assay to identify Brucella abortus biovars 5, 6 and 9 and the new subgroup $3 b$ of biovar 3. Vet Microbiol, 110, 41-51.
21. Refai M (2002): Incidence and control of brucellosis in the Near East region. Vet Microbiol, 90, 81-110.

22. Sümerkan B, Gökahmetoglu S, Esel D (2001): Brucella detection in blood: comparison of the BacT/Alert standard aerobic bottle, BacT/Alert FAN aerobic bottle and BacT/Alert enhanced FAN aerobic bottle in simulated blood culture. Clin Microbiol Infect, 7, 369-393.

23. Şahin M, Genç O, Ünver A, Otlu S (2008): Investigation of bovine brucellosis in the Northeastern Turkey. Trop Anim Health Product, 40, 281-286.

24. Şimşek H, Erdenlig S, Oral B, Tülek N (2004): Typingbiotyping of Brucella isolates of human origin and their epidemiologic evaluation. Klimik Derg, 17, 103-106.

25. Ünver A, Erdoğan HM, Atabay Hi, Şahin M, Çelebi Ö (2006): Isolation, identification, and molecular characterization of Brucella melitensis from aborted sheep fetuses in Kars, Turkey. Revue Vet Med, 157(1), 42-46.

26. Yu WL, Nielsen K (2010): Review of Detection of Brucella spp. by Polymerase Chain Reaction. Croat Med J, 51, 306-313.

Geliş tarihi: 13.01.2012 / Kabul tarihi: 25.04.2012

\author{
Address for correspondence: \\ Dr. Arzu Findik \\ Ondokuz Mayıs Üniversitesi \\ Veteriner Fakültesi \\ Mikrobiyoloji Anabilim Dal \\ Kurupelit Kampüsü. Atakum, Samsun, TÜRKIYE. \\ E-mail:afindik@omu.edu.tr
}

